\title{
Personal Selling, Sales Promotion, and Intention Revisit: The Mediating Role of Reputation
}

\author{
Abdul Kadir, Syamsul Ridjal, and Herman Sjahruddin
}

\begin{abstract}
The role of reputation as a mediator is used to explain the causality between personal selling and sales promotion with revisit intention. This research is an explanatory research, which aims to collect data from various sources and to verify the responses of 149 visitors to Nipah Mall Makassar. In testing the hypothesis, the data were analyzed using WarpPLS 7.0 analysis, the results of the study showed evidence that partially personal selling and sales promotion had a positive but insignificant effect on revisit intention but proved to have a significant effect on good reputation. reputation contributes positively and significantly in increasing revisit intention. The resulting mediation effect provides evidence that reputation can strengthen the relationship between personal selling and sales promotion with revisit intention.
\end{abstract}

Index Terms - Personal selling, reputation, revisit intention, sales promotion.

\section{INTRODUCTION}

Covid-19 that has hit the world has resulted in people engaging in social distancing, thus limiting their activities. The high spread of covid-19 has resulted in a high mortality rate so that business activities have become paralyzed due to the prohibition of people from doing activities the outside home [1]. This condition has an impact on the emergence of boredom from the community. The saturation that occurred for a relatively long time resulted in people looking for all kinds of ways to suppress this saturation.

In some cases, this saturation can be minimized through the high level of human activity to shop online. However, this condition did not last long because of the human desire to carry out consumption activities by visiting the shopping center which they used as a family tourist spot. In Indonesia, the desire to minimize this situation is also carried out by visiting shopping centers that they use as well as family tourism spots.

Makassar city is one of the provinces in Indonesia which has a modern shopping center that can be used as a means of family tourism, one of these shopping centers is Nipah Mall Makassar. At the time of the detection of Covid-19 in

Published on December 11, 2020.

Abdul Kadir, Sekolah Tinggi Ilmu Ekonomi Makassar Bongaya (STIEM Bongaya), Indonesia.

(e-mail: abdulkadir199381@gmail.com)

, Sekolah Tinggi Ilmu Ekonomi Makassar Bongaya (STIEM Bongaya), Indonesia.

(e-mail: syamsulridjal ${ }^{@}$ stiem-bongaya.ac.id)

Herman Sjahruddin, Sekolah Tinggi Ilmu Ekonomi Makassar Bongaya (STIEM Bongaya), Indonesia.

(e-mail: herman.sjahruddin ${ }^{\circledR}$ stiem-bongaya.ac.id).
Makassar, the level of community visits to the Nipah Mall decreased drastically, but after the enactment of leniency from the local government by requiring people to apply of $3 \mathrm{M}$, namely washing hands with soap in running water, maintaining distance, and wearing masks. In July 2020, gradually the public's interest in visiting shopping centers began to increase, one of the shopping centers that began to experience an increase, namely Nipah Mall Makassar. The factors that influence the public's interest in visiting shopping centers are reputation, personal selling, sales promotion, good customer service, reasonable prices, and corporate identity [2], [3], [4]. Among these factors, there are several important factors, namely reputation, personal selling, sales promotion and Corporate Identity.

Visiting interest is a central theme in business, it focuses on the relationship between antecedent, deliberate, and mental actions involved in practical reasoning. Therefore, interest appears in response to stimuli received by individuals [5]. Someone who has an interest in him, of course, will first look for various information about the product or service they want, then this will be followed by a decision to buy. The expert's view explains that the buying decision or visiting decision is an activity to buy a trademark that is the most preferred of the various alternatives available [6]. When someone is interested in visiting a certain place, then of course it will arise in him to find information related to the object to be visited, the experience of visiting consumers if the experience is positively correlated with their expectations, then they will occur confirmation reverse otherwise it will become a disconfirmation [7].

Confirmation can be created if it is supported by personal selling, sales promotion, good customer service, reasonable price, and Corporate Identity. The company's goal of personal selling is to convince customers that the products and services offered by the company are the best to meet consumer needs. Personal selling is direct communication (face to face) between sellers and potential consumers to introduce a product or service to potential consumers by forming an understanding of the product so that potential consumers will then try to buy it [8]. Previous research has provided evidence that personal selling effective has been shown to increase interest in returning to visit, this is due to a person's ability to establish good relationships with potential customers [9], but different from the findings of other research [10], his research results explain that personal selling is not proven to have a significant effect on consumer purchase interest.

Another factor that plays an important role in increasing 
interest in returning to visit is sales promotion. Sales promotion is a key element in any marketing campaign. The expert's view explains that sales promotion consists of a collection of various incentive tips, most of which are short term, designed to encourage the purchase of a certain product / service more quickly and or more by consumers and merchants [6]. There is some empirical evidence in explaining the relationship between sales promotion and visiting interest, such as the findings research that the sales promotions which are part of the promotional mix have a significant effect on tourist visiting decisions [11]. The empirical evidence that companies that are able to carry out sales promotions properly will be able to increase consumer interest in making repeat purchases [12]. That the sales promotion is not significant for interest [13].

Personal selling and sales promotion, variable reputation also affects a person's interest in making decisions both in shopping decisions and decisions in choosing a place to visit. The attitude and actions of people towards an object are largely determined by the reputation of the object. The reputation of the company itself is abstract or intangible, but its form can be felt from the results of assessment, acceptance, awareness and understanding, both a kind of sign of respect and respect, from the surrounding public or the wider community towards the company as a business entity or its personnel [14]. Reputation is something that is inherent in the company but cannot be seen and measured because it is not in the form of a product, but the existence of a strong reputation can have an influence in strengthening the company's position in facing competition.

The reputation has a significant influence on consumer interest in making purchases [15], a similar result is evidenced by the researcher [16], providing an explanation that reputation does not play an important role in purchase intention. Brand image reflects a good reputation and has an impact on the interest in returning visits by customers. personal selling and sales promotion as well as a good reputation will certainly have a real impact in increasing the interest in community visits, however this will be even more significant if supported by a corporate identity [17]. This is in accordance with the findings of [18], providing evidence that corporate identity, which is a representation of corporate image, plays an important role in increasing the influence of the promotional mix in the marketing mix on visiting interest.

\section{LITERATURE REVIEW AND HYPOTHESIS}

\section{A. Personal Selling}

The marketing mix method, namely personal selling, is an important step that companies can take to persuade potential customers, although there are other media that also promote products or services, this is in accordance with the results of research on the contribution of personal selling in marketing activities, especially in current conditions [19].

The expert's view explains that personal selling is a personal presentation by salespeople of the company in order to succeed in sales and build relationships with customers. In addition to these views, other researchers also explain that personal selling is an activity of interaction between individuals, where they meet face to face with the aim of creating, improving, controlling, or maintaining mutually beneficial exchange relationships with other parties [20]. Both the poor personal selling in this study is measured by indicators such as direct information, use of language, and interesting information.

Relations personal selling with interest has been analyzed by several previous experts such [9], analyzing personal selling of interest in visiting, the results of which are significant for interest in returning to visit. This finding was reinforced by further researchers who explained that promotional mix activities had a significant effect in increasing interest in visiting. Besides having an effect on consumer interest, in addition to having an influence on someone's interest, personal selling related to the reputation variable, where companies that are able to promote intensely, of course, will have an impact on the company's image, in this case the company's reputation, all of them prove that the promotional mix consisting of personal selling and sales promotion has a significant effect on the reputation of a company which is part of the brand image [21]. Based on this explanation, a hypothesis was built in this study in describing the relationship between variables. Based on this, the hypothesis is built in this study:

$\mathrm{H}_{1 \mathrm{a}}$ : Personal selling has a positive relationship with revisit intention

$\mathrm{H}_{1 \mathrm{~b}}$ : Personal selling has a positive relationship with reputation

\section{B. Sales Promotion}

The Key elements of a successful marketing campaign lies in a sales promotion. The expert's view explains that sales promotion consists of a collection of various incentive tips, most of which are short term, designed to encourage the purchase of a certain product / service more quickly and or more by consumers and merchants [6], another view suggests that sales promotion refers to any incentives that producers use in trade (for wholesalers, retailers, or other channel members), for consumers to buy their products / brands, and to encourage salespeople to be more aggressive in selling their products/brands [22].

Both the poor sales promotion measured by indicators of activity sponsored, effectiveness in conducting sweepstakes and effectiveness in conducting the event. Proof of relationship sales promotion of the interests described by the results of research [11] and [12], in their findings explain a significant relationship between sales promotions can improve consumer interest. Meanwhile, other researchers explain that promotion as measured by sales promotion contributes significantly to tourism image [23]. So, the hypothesis of this study:

$\mathrm{H}_{2 \mathrm{a}}$ : Sales Promotion has a positive influence on revisit intention

$\mathrm{H}_{2 \mathrm{~b}}$ : Sales Promotion has a positive effect on reputation

\section{Reputation}

The company's reputation is a form of customer trust in the products or services of the company concerned so that it will influence customers in making choices [24]. Reputation is one of the important points of success that a company has achieved for its focus on a business. The focus of the 
company is to show competence, trust and excellence that have been cultivated so that it has positive values in facing competition in the business world. Reputation in this study is measured by indicators of good name in the eyes of customers, business ethics, and company performance. Research evidence from experts explains that reputation has a significant influence on interest in returning visits by customers [17].

$\mathrm{H}_{3}$ : Reputation has a positive effect on revisit intention

\section{Visiting interests}

Visiting interest in this research is represented by buying interest. This study uses Theory of Planned Behavior (TPB) to explain the Visiting Interest variable which is defined as the possibility of visiting a place that is felt within a certain period of time. This interest in visiting appears as a form of someone's response to a place [25]. Other experts argue that interest is defined as the will, desire or liking [26]. Interest is something that is personal and has a close relationship with attitude. Where both are precursors to prejudice, interest has to do with decision making. Interest will influence someone to actively do something in order to get to a place that makes him interested.

The better the promotion mix carried out by the company, which is reflected through personal selling and sales promotion activities, of course this will not only have an impact on the company's reputation as has been proven [21], but of course it will have an indirect influence on one's interests. to use or re-consume the products or services offered. then based on this, a hypothesized indirect effect was built in this study:

$\mathrm{H}_{4}$ : Personal selling has a positive effect on revisit intention through reputation

$\mathrm{H}_{5}$ : Sales Promotion has a positive influence on interest in visiting through Reputation

\section{METHODS}

Based on the type of research, this research is explanatory research, namely research used to obtain data from a certain place, but the researcher performs treatment in data collection, for example distributing questionnaires, tests, interviews and so on [27]. The number of samples used was 149 respondents, consisting of 66 men and 83 women. Hypothesis testing in this study uses analysis techniques Structural Equation Modeling (SEM) using assistance structural Partial Least Square (PLS) Version 7.0.

\section{RESULTS}

There are two evaluation models, namely, the measurement model (Outer Model) and the structural model (Inner Model) in WarpPLS. The test results can be explained as follows:

\section{A. Outer Model}

1. Convergent validity

The data is assumed to meet the test convergent validity if the value of lambda> 0.70. the interpretation of the test results is described in the table abov: a) Personal selling, from the results of the combined loading and cross-loading output, it shows that all indicators in the variable have a value $=>0.70$, which is in the range $0.817-0.911$, with a significant level $=$ $<0.05$. Then the validity test is fulfilled

b) Sales promotion, the value generated in the table above proves that all construct indicators meet the data validity test $=>0.70$, with the highest value 0.881 and the lowest 0.782

c) Reputation, the test results provide evidence that there are no indicators whose validity values are not fulfilled, where the resulting value $=>0.70$, namely in the range $0.920-0.930$.

d) Revisit intention, the value generated in the test explains that the indicators used to measure the construct have a value $=>0.70$, so that the validity test is fulfilled.

TABLE I: COMBINED LOADING AND CROSS-LOADING

\begin{tabular}{cccccc}
\hline \hline Construct & PS & SP & RPT & RIT & P value \\
\hline \hline PS1 & 0.817 & & & & $<0.001$ \\
PS2 & 0.911 & & & $<0.001$ \\
PS3 & 0.892 & & & $<0.001$ \\
SP1 & & 0.877 & & & $<0.001$ \\
SP2 & & 0.782 & & & $<0.001$ \\
SP3 & & 0.881 & & & $<0.001$ \\
RPT1 & & & 0.930 & & $<0.001$ \\
RPT2 & & 0.920 & & $<0.001$ \\
RPT3 & & 0.928 & & $<0.001$ \\
RIT1 & & & 0.756 & $<0.001$ \\
RIT2 & & & 0.884 & $<0.001$ \\
RIT3 & & & 0.731 & $<0.001$ \\
\hline \hline
\end{tabular}

2. Discriminant validity

After the validity test is fulfilled, the next test on the measurement model is discriminant validity, a data is said to fulfill the discriminant test if the loading value to another construct (cross-loading) is lower than the loading to the variable construct itself.

TABLE II: VIEW COMBINED LOADING AND CROSS-LOADINGS

\begin{tabular}{ccccc}
\hline \hline \multirow{2}{*}{ Construct } & \multicolumn{4}{c}{ Value Loading into Other Constructs } \\
& PS & SP & RPT & RIT \\
\hline \hline PS1 & 0.817 & 0.409 & 0.105 & -0.202 \\
PS2 & 0.911 & 0.015 & 0.081 & -0.017 \\
PS3 & 0.892 & -0.389 & -0.178 & 0.203 \\
SP1 & -0.539 & 0.877 & 0.062 & -0.011 \\
SP2 & 0.644 & 0.782 & -0.175 & 0.183 \\
SP3 & -0.035 & 0.881 & 0.094 & -0.152 \\
RPT1 & -0.039 & 0.028 & 0.930 & 0.180 \\
RPT2 & 0.068 & -0.159 & 0.920 & 0.021 \\
RPT3 & -0.028 & 0.129 & 0.928 & -0.201 \\
RIT1 & 0.352 & -0.006 & -0.751 & 0.756 \\
RIT2 & -0.091 & 0.140 & 0.394 & 0.884 \\
RIT3 & -0.254 & -0.164 & 0.300 & 0.731 \\
\hline \hline
\end{tabular}

Table 2. provides an explanation that all research variables have a loading value for other constructs that is lower than the loading value for the construct itself in the same column. Then the test is fulfilled so that it can be continued on composite reliability

3. Composite reliability

The third part of the outer model is composite reliability. The assessment of composite reliability is done by looking 
at the output from the view of the latent variable coefficients. The criteria are seen from two things, namely composite reliability, and Cronbach's alpha $=>0.70$ [28], [29].

TABLE III: COMPOSITE RELIABILITY

\begin{tabular}{ccccc}
\hline \hline MODEL & PS & SP & RPT & RIT \\
\hline \hline R-Squared & & & 0.527 & 0.719 \\
R-squared coefficients & & & 0.521 & 0.713 \\
Composite Reliab. & 0.907 & 0.884 & 0.948 & 0.835 \\
Cronbach's Alpha & 0.845 & 0.802 & 0.917 & 0.701 \\
Avg. Var. Extrac. & 0.765 & 0.718 & 0.858 & 0.629 \\
Full Collin. Vif & 2.843 & 2.327 & 3.682 & 2.813 \\
Q-Squared & & & 0.528 & 0.650 \\
\hline \hline
\end{tabular}

The composite of sales promotion value $=0.907>0.70$, sales promotion $=0.884>070$, construct is reputation $=$ $0.948>0.70$ while revisit intention has a value $=0.835>$ 0.70 , for the value cronbach's of all variables $=>0.70$, this indicates the fulfillment of this test.

\section{B. Inner Model}

\section{1) Goodness of fit model}

Testing of the goodness of fit model explains the feasibility of the analysis model, the test standards are based on the significance value $<0.05$.

TABLE IV: GOODNESS OF FIT (INNER MODEL)

\begin{tabular}{cc}
\hline \hline Goodness of fit & Index \\
\hline \hline Average path coefficient (APC) & 0.341 \\
Average R-squared (ARS) & 0.623 \\
Average adjusted R-squared (AARS) & 0.617 \\
Average full collinearity VIF (AFVIF) & 2.916 \\
\hline \hline
\end{tabular}

The value of Average path coefficient $($ APC $)=0341(p-$ value $<0.001)$, Average R-squared $(A R S)=0623$ (p-value $<0.001$ ), while the adjusted R-squared Average (AARs) = 0617 (p-value <0.001). These results explain the testing inner model for goodness of fit is met, and the model to be feasible to be continued in the next analysis.

2) Path coefficient test, and Q-square

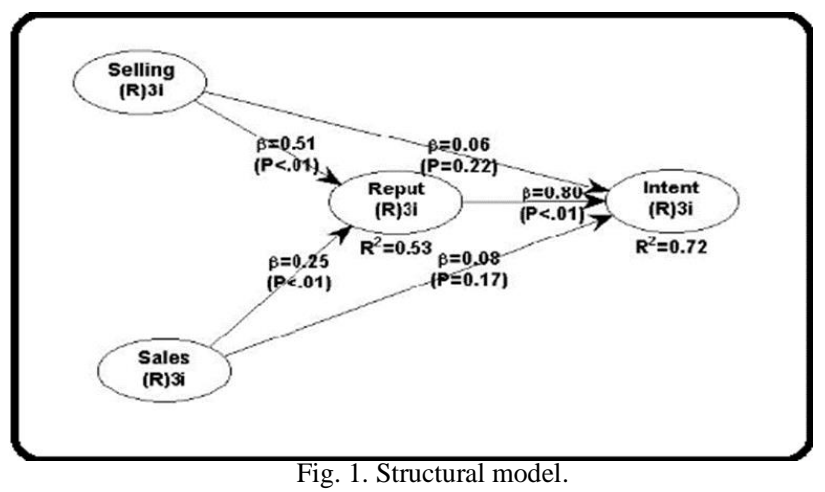

Table inner path coefficient models and drawings show the value of $\mathrm{R} 2=0.72$, it is clear that the predictor variables were used in this study amounted to $72 \%$ and the remaining $28 \%$ are influenced by other factors not described in this study. Then by leaning on the Q-Squared value. 0.650 or $65 \%$. This indicates that a good relationship in this study is the relationship between personal selling and sales promotion variables on revisit intention mediated by reputation.

3) Hypothesis testing

Relationship between variables based on the previous test results is shown in the path coefficient and p-value as the basis for acceptance of the hypothesis:

TABLE V: DIRECT AND INDIRECT EFFECTS

\begin{tabular}{|c|c|c|c|c|c|c|c|c|}
\hline \multicolumn{5}{|c|}{ Path Coefficient } & \multicolumn{4}{|c|}{$P$ Values } \\
\hline Var. & PS & SP & RPT & RIT & PS & SP & RPT & RIT \\
\hline \multicolumn{9}{|l|}{$\begin{array}{l}\text { PS } \\
\end{array}$} \\
\hline \multicolumn{9}{|l|}{ SP } \\
\hline \multirow[t]{2}{*}{ RPT } & 0.51 & 0.25 & & & $<0.00$ & $<0.00$ & & \\
\hline & 5 & 2 & & & 1 & 1 & & \\
\hline \multirow{2}{*}{ RIT } & 0.06 & 0.07 & 0.79 & & 0.216 & 0.167 & $<0.00$ & \\
\hline & 4 & 8 & 7 & & & & 1 & \\
\hline MDS & & & & 0.41 & & & & $<0.00$ \\
\hline 1 & & & & 1 & & & & 1 \\
\hline MDS & & & & 0.20 & & & & $<0.00$ \\
\hline 2 & & & & 1 & & & & 1 \\
\hline$\overline{\mathrm{PS}}$ & & Personal & Selling & & & & & \\
\hline SP & & Sales $\operatorname{Pr}$ & notion & & & & & \\
\hline RPT & & Reputati & & & & & & \\
\hline RIT & & Revisit I & tention & & & & & \\
\hline MDS1 & & P.selling & $\rightarrow$ repu & tion $=$ & R.Inter & & & \\
\hline MDS 2 & & S.Prome & on $\rightarrow 1$ & putatic & $\rightarrow$ R.I & ention & & \\
\hline
\end{tabular}

\section{Personal Selling $\rightarrow$ Revisit Intention}

Promotion Is a means used to provide information, persuade, and remind customers about the products the company sells [6]. One of the promotional mixes is personal selling. Personal selling is a presentation made orally by someone in conversation with potential customers with the aim of creating a sale. The results of hypothesis testing show that the path coefficient value is 0.064 (p-value 0.216) that personal selling has a positive and insignificant effect on revisit intention. This indicates that the personal selling variable has a high influence but has not been able to make a real contribution to increasing revisit intention. The coefficient which is positive shows that the promotional activities carried out by the company in the form of personal selling are classified as good, this is due to the ability of employees to convey information that is easily understood by prospective visitors about the place, but the insignificant effect is due to the existence of several supporting facilities. which cannot be used by visitors such as the number of toilets that cannot be used. This situation makes visitors feel that what they want is not suitable for field conditions. These findings are in line with [10], that personal selling is not proven to be able to increase consumer interest

\section{Personal Selling $\rightarrow$ Reputation}

Promotions carried out by the company, in this case personal selling, is expected to improve the company's reputation. With these activities the company expects prospective visitors to know the products or services offered. The test results show that the path coefficient value $=0.515$ ( $\mathrm{p}$-value $<0.001)$ that personal selling has a positive and significant effect on reputation. These results explain that the effect of personal selling on reputation is high and is able to increase reputation. The high influence of personal selling carried out by the company in introducing the products or services offered is due to the ability of employees to provide information that attracts the attention 
of visitors, then the significant effect generated is due to management always running its business by applying good ethics to visitors. high trust in the products and services offered. The results of this study are in line with the findings of [21], with good personal selling, it will be able to increase the image of the company in the eyes of its consumers or customers.

\section{Sales Promotion $\rightarrow$ Revisit Intention}

Sales promotion is one aspect of the promotional mix. It is hoped that the sales promotion, either from giving gifts, or discounts, etc., can attract visitors to make visits or purchases. The path coefficient value $=0.078$ ( $\mathrm{p}$-value 0.167) proves that sales promotion has a relatively high influence but has not been able to increase revisit intention. The coefficient which is positive indicates that the sales promotion activities implemented by the company have been good so that it has a strong influence. This is because the company always carries out drawing activities to attract visitors so that they wish to visit the place. However, the insignificance of this influence is due to the fact that there are still many tenants or outlets that are not yet open so that visitors feel that the benefits obtained while visiting are still low because they do not get the items they are looking for or want. These results do not support the findings [11] and [12], in increasing consumer interest, sales promotion activities play an important role in it.

\section{Sales Promotion $\rightarrow$ Reputation}

Carrying out a sales promotion, it will accelerate attracting consumers or customers who are looking for low prices and are happy to change brands, so that it will generate high sales responses in the short term but little permanent gain in market share. And with the existence of a good sales promotion, of course, it will make the company's good name even better if what is being promoted is in accordance with what the customer gets. The path coefficient value $=0.252$ ( $\mathrm{p}$-value $<0.001)$ proves that sales promotion has a positive and significant effect on reputation, this provides evidence that the higher the sales promotion carried out by the company, it will be able to increase the company's reputation.

Another thing explains that the influence created between sales promotion and reputation is a strong relationship and is able to make a real contribution to improving reputation. The high sales promotion carried out by the company can be seen from the intense activities held by the event to attract visitors or consumers. The significant influence that is generated is due to the fact that the company often holds, the company has been known among the public as a company that has high performance both from the products or services offered. The results of this study reinforce the findings [23], that sales promotion will be able to improve the image or reputation of a company.

\section{Reputation $\rightarrow$ Revisit Intention}

Reputation is something that is difficult to measure and its existence is due to the existence of a different reputation from products that can be seen (intangible), but reputation can be known through the results of research whether the public's views are good or bad. A company that has a good reputation will certainly have a positive value in the eyes of the community. The test results on the path coefficient value $=0.797$ ( $\mathrm{p}$-value $<0.001)$. This proves that reputation has a positive and significant effect on revisit intention. Based on these results it can be interpreted that reputation has a high influence so that it can increase the interest in returning to the community. Another result explains that the better the reputation of the company, the higher the interest in visiting.

The high influence of reputation is due to the ability of management to show its current performance achievement to society through a high level of concern for the needy community. The significance of the resulting effect on revisit intention is due to the fact that visitors have high trust in companies that offer their services or products, which is an impact of the level of corporate social care. The results of this study reinforce the findings [17] that a good company reputation will be able to increase customer interest in visiting again.

\section{Personal Selling $\rightarrow$ Reputation $\rightarrow$ Revisit Intention}

Good personal selling, it will certainly make it easier to establish good relationships between sellers and potential customers and will make it easier to provide information about service products to be offered, with the promotion mix, namely personal selling, of course, will have an impact on the company's reputation because it is able to establish relationships. good with prospective customers, then will have an influence on the increasing interest of consumers to visit. The results of the indirect effects test have a path coefficient value $=0.411$ (p-value $<0.001)$. These results explain that the variable reputation has a strong influence so that it can mediate the relationship between personal selling and revisit intention. In addition, it can also be explained that reputation can act as a mediator in explaining the effect of personal selling on revisit intention. As for the nature of the mediation model, it is stated as complete mediation.

\section{Sales Promotion $\rightarrow$ Reputation $\rightarrow$ Revisit Intention}

The better the promotion mix, especially in terms of sales promotion, will certainly be a positive value in the eyes of the public or consumers that the company has high performance and this has an impact on the company's reputation and consumer interest in visiting, the results of the indirect effects test have a path coefficient value $=0.201$ (p-value < 0.001). These results explain that a good reputation variable will be able to increase the effect of sales promotion on revisit intention. These results indicate that the role of reputation is very important in explaining the significant relationship between sales promotion and revisit intention. As for the nature of the mediation model, it is stated as complete mediation.

\section{CONCLUSION}

Promotional activities carried out by companies in this case personal selling and intense sales promotions cannot increase someone's interest in visiting, this is because the information provided is not fully in accordance with what they imagine as there are still some facilities that can be used, besides, there are still many tenants or outlets that are not yet open. The role of mediating reputation is proven to be able to explain the causality between personal selling and sales promotion with revisit intention. So that the social care given by the company and good ethics in running its 
business will be able to create a strong desire for consumers to visit again.

\section{REFERENCES}

[1] Suprihatin, W. (2020). Analysis of Tourist Consumer Behavior in the Covid-19 Pandemic Era (Case Study of Tourism in West Nusa Tenggara). Bestari, 1(1), 56-66.

[2] Ismagilova, E., Slade, EL, Rana, NP, \& Dwivedi, YK (2019). The effect of electronic word of mouth communications on intention to buy: a meta-analysis. Information Systems Frontiers, 1-24.

[3] Hamdan, Y., Ratnasari, A., Sofyan, A., \& Yuniati, Y. (2020, March). Personal Selling Skill in Building Interaction with Consumers. In 2nd Social and Humaniora Research Symposium (SoRes 2019) (pp. 262 266). Atlantis Press.

[4] Mbilinyi, E. (2020). Sales Promotion in Stimulating Stronger Market Response at Mlimani City Mall in Dar es Salaam (Doctoral dissertation).

[5] Alhasbi, F. (2020). Possible Elaboration: Quality As Message In Affecting Satisfaction And Returning Interest. Source: Journal of Communication Sciences, 6(2), 239-249.

[6] Kotler, Philip. (2012). Marketing Management. Edition 13 Volume One. Jakarta: Erlangga.

[7] Musdalifah, A. (2020). The influence of facilities, prices and employee services on visitor satisfaction at the Tirto Joyo swimming pool (Doctoral dissertation, IAIN Ponorogo).

[8] Ramli, A. H., \& Sjahruddin, H. (2015). Building patient loyalty in healthcare services. International Review of Management and Business Research, 4(2), 391.

[9] Ikhwan, R.A. (2020). The Influence of Advertising, Sales Promotion and Personal Selling on Tourist Decisions to Visit Mangroove Sari Dukuh Pandansari, Kaliwlingi Village, Brebes Regency (Doctoral dissertation, Pancasakti University).

[10] Abdurrahim, A., \& Sangen, M. (2019). The influence of content marketing, sales promotion, personal selling, and advertising on consumer buying interest at the Biuti hotel in Banjarmasin. Journal of management science and entrepreneurship, 3 (1), 42-47.

[11] Hartyanto, B.N., \& Pangestuti, E. (2020). The Effect of Tourism Promotion on the Decision to Visit International Tourists to Odtw (Survey at the Tourist Information Center Malioboro Yogyakarta City). Journal of Business Administration, 77 (1).

[12] Alvian, M. S., \& Prabawani, B. (2020). The effect of sales promotion and product diversity at shopees on repurchase interest through customer satisfaction as an intervening variable. Journal of Business Administration Science, 9 (2), 191-200.

[13] Kristiyadi, K., \& Hartiyah, S. (2017). The Influence of Reference Groups, Religiosity, Promotion and Knowledge of Sharia Financial Institutions on Saving Interest in Sharia Financial Services Cooperatives (Case Study at BMT Tamzis Wonosobo). Journal Of Economics And Informatics Engineering, 4 (2), 44-63.

[14] Ramadhani, A. F., Sufian, S., \& Soesanto, H. (2013). Analysis of the influence of promotions, community effects, company reputation, prices, and competence of marketing personnel to consumer interest took credit at PT BPR Weleri Makmur Semarang (Doctoral dissertation, Diponegoro University).

[15] Shahnaz, N. B. F., \& Wahyono, W. (2016). Factors Affecting Consumer Purchase Interest in Online Stores. Management Analysis Journal, 5(4).

[16] Agustin, C. A., \& Hellianto, G. R. (2020). Effect of Reputation on Interest in Buying Skincare Products at Shopee. Business Economic, Communication, and Social Sciences (BECOSS) Journal, 2(1), 39-52.

[17] Prasetyo, A. (2020). The Role of Experiential Marketing In Encouraging Customer Satisfaction, Brand Image And Word Of Mouth So As To Increase Customer Interest In Returning Customers To Sharia Banks (Case Study of Bank BRI Syariah KCP Magelang).

[18] Sawaftah, D., Calicioglu, C., \& Awadallah, R. (2020). The relationship between viral marketing and consumer purchase intention, the moderator role of brand image and age: Evidence from smartphone users in North Cyprus. Management Science Letters, 10(6), 1307-1320.

[19] Kusniadji, S. (2017). Contribution of the Use of Personal Selling in Marketing Communication Activities in Today's Marketing Era. Journal of Communication, 9 (2), 176-183.

[20] Swastha, Basu. (2014). Sales Management. Yogyakarta: BPFE.

[21] Budianto, Y. P., \& Budiatmo, A. (2019). The Effect of Promotion and Product Quality on Purchasing Decisions with Brand Image as a Mediation Variable. Journal of Business Administration Science, 10 (1), 220-229.
[22] Shimp, Terence. (2011). Integrated Marketing Communication in Advertising and Promotion. Jakarta: Salemba Empat.

[23] Sulthony, Z. (2015). The effect of the promotion mix on the formation of the image of Berastagi cultural tourism, Karo district, North Sumatra province. Scientific Journal of Management and Business, 14 (2).

[24] Simamora, V., \& Celeste, C. (2017). The effect of the company's reputation on purchasing decisions with consumer confidence as intervening variables (Case Study on Consumers of Aqua Brand Gallons of Drinking Water in Tanjung Priok District, North Jakarta) Managerial Accounting Journal, 2(2), 24-36.

[25] Whang, H., Yong, S., \& Ko, E. (2016). Pop culture, destination images, and visit intentions: Theory and research on trave motivations of Chinese and Russian tourists. Journal of Business Research, 69(2), 631-641.

[26] Sinurat, H., Silvia, I., \& Sabrin, S. (2020). Marketing communication strategy in increasing interest in visiting the state museum of north sumatra province. Message: Jurnal komunikasi, 9(1), 62-71.

[27] Sugiyono, (2017). Statistics For Research. Twenty Seven Prints, Publisher: Alfabeta, Bandung.

[28] Arista, OE (2016). The Influence of Perceptions on Corporate Social Responsibility on Job Satisfaction and Organizational Commitment (survey on V Star Hotels in Yogyakarta). Essay.

[29] Razak, N., Themba, O. S., \& Sjahruddin, H. (2019). Brand awareness as predictors of repurchase intention: Brand attitude as a moderator. Advances in Social Sciences Research Journal, 6(2), 541-554. 